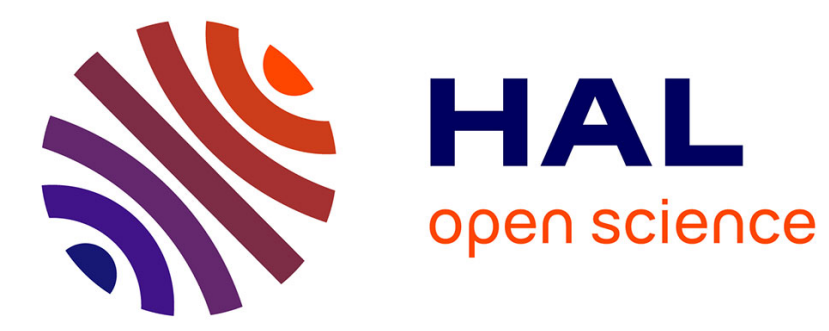

\title{
Macroscopic amoxicillin crystalluria
}

Maxime Hentzien, Dorothée Lambert, Anne Limelette, Yohan N'Guyen, Ailsa Robbins, Delphine Lebrun, Roland Jaussaud, Firouzé Bani-Sadr

\section{To cite this version:}

Maxime Hentzien, Dorothée Lambert, Anne Limelette, Yohan N'Guyen, Ailsa Robbins, et al.. Macroscopic amoxicillin crystalluria. The Lancet, 2015, 385 (9984), pp.2296. 10.1016/S0140-6736(14)620018. hal-02883079

\section{HAL Id: hal-02883079 \\ https://hal.science/hal-02883079}

Submitted on 28 Jun 2020

HAL is a multi-disciplinary open access archive for the deposit and dissemination of scientific research documents, whether they are published or not. The documents may come from teaching and research institutions in France or abroad, or from public or private research centers.
L'archive ouverte pluridisciplinaire HAL, est destinée au dépôt et à la diffusion de documents scientifiques de niveau recherche, publiés ou non, émanant des établissements d'enseignement et de recherche français ou étrangers, des laboratoires publics ou privés. 


\section{Macroscopic amoxicillin crystalluria}

Maxime Hentzien, Dorothée Lambert, Anne Limelette, Yohan N'Guyen, Ailsa Robbins, Delphine Lebrun, Roland Jaussaud, Firouzé Bani-Sadr

A 62-year-old woman was referred to our hospital in September, 2013, with fever, arthralgia, and dyspnoea lasting for 6 days. Her medical history was uneventful apart from hypertension and active tobacco use. Blood cultures on admission grew Streptococcus agalactiae and acute aortic infective endocarditis was rapidly diagnosed with transoesophageal echocardiography. She was immediately started on high-dose intravenous amoxicillin (200 mg/kg per day) with intravenous gentamicin (240 mg once-daily). After 4 days, we noticed cloudy urine, with a thin granulation[A: granular?] appearance (figure). Her urine $\mathrm{pH}$ was 5.5. Direct examination of the urine showed amoxicillin crystalluria with large, typically aggregated needle-shaped crystals (figure) that were birefringent under polarised light microscopy. Her clinical condition worsened with oliguria, acute renal failure, and pulmonary oedema within $24 \mathrm{~h}$. An aortic ring abscess was evident on a second echocardiography. After emergency valve replacement surgery and renal replacement therapy, she recovered well and was discharged home in October, 2013, without further renal replacement therapy, and with improving renal function. Her last glomerular filtration rate was $45 \mathrm{~mL} / \mathrm{min}$ per $1.73 \mathrm{~m}^{2}$ [A: please add normal range as a reference for readers] in March, 2014. At last follow-up, in September, 2014, patient was asymptomatic. [A: has patient had more recent follow-up? Has anything

changed in her clinical condition?] amoxicillin crystalluria could have played a part. crystalluria. Written consent to publication was obtained.
Amoxicillin is known to cause urine crystallisation, although its incidence is unknown. Amoxicillin crystalluria usually occurs with high-dose amoxicillin therapy, in urines that have a low $\mathrm{pH}$ and are highdensity (mainly due to insufficient fluid intakes). Amoxicillin crystalluria can be microscopic or macroscopic. The typical microscopic appearance described here is usually sufficient for diagnosis in a compatible context but the amoxicillin composition of these crystals can be confirmed by infrared spectroscopy if needed. Amoxicillin crystalluria can be asymptomatic or can be responsible for haematuria or acute renal failure attributable to intratubular precipitation or urinary tract obstruction. In our patient, acute renal failure was multifactorial, but we speculate that

Physicians should be aware of such a complication of amoxicillin because high intravenous doses are frequently prescribed worldwide and because urine alkalinisation and increased fluid intake might prevent

All authors cared for the patient and contributed to writing of the report.

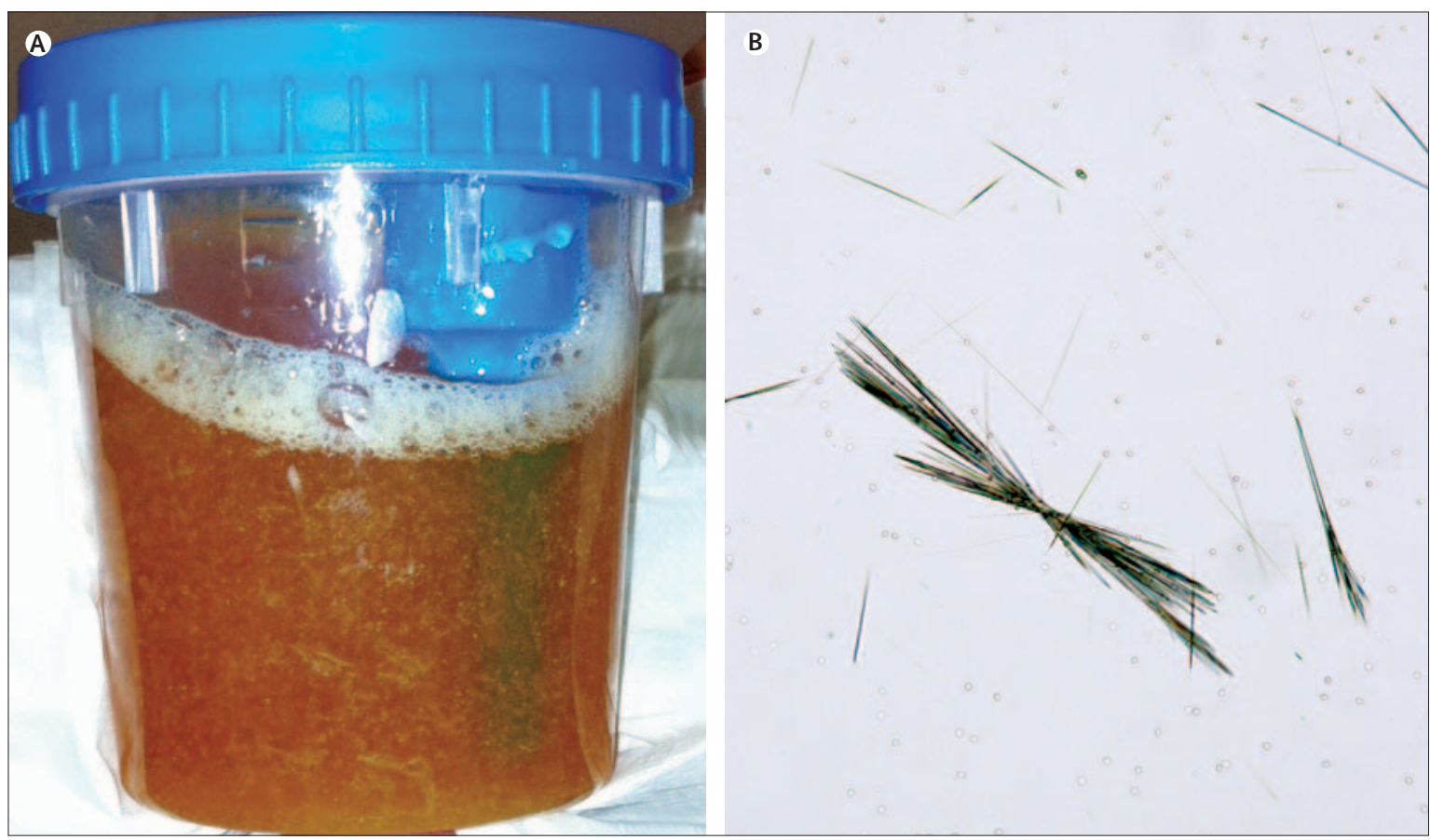

Figure: Cloudy urine with a granular appearance (A) containing large typically aggregated needle-shaped crystals of amoxicillin (B). [A: we need a short figure caption. Please amend if needed]

@(@)

Published Online February 11, 2015 http://dx.doi.org/10.1016/ S0140-6736(14)62001-8

Service de Médecine InterneMaladies infectieuses, Immunologie Clinique, Centre Hospitalier Universitaire Robert Debré, Reims, France (M Hentzien MD, D Lambert MD Y N'Guyen MD, A Robbins MD, D Lebrun MD,

Prof R Jaussaud PhD

Prof F Bani-Sadr PhD); and Laboratoire de bactériologieLaboratoires centraux, Centre Hospitalier Universitaire

Robert Debré, Reims, France (A Limelette MD)[A: addresses okay as added?][A:Please indicate if any of the other authors are full professors] Correspondence to: $\operatorname{Dr}[\mathrm{A}:$ correct?]

Maxime Hentzien, Service de Médecine Interne-Maladies infectieuses, Immunologie Clinique, Centre Hospitalier Universitaire Robert Debré, Avenue du général Koenig 51092 Reims Cedex, France mhentzien@chu-reims.fr 